\title{
Screening of cellulose- and lignin-degrading fungi for improving nutritive quality of ruminant feed
}

\author{
Muhammad Fauzi ${ }^{1, *}$, Nisa Rachmania Mubarik $^{2}$, and Anuraga Jayanegara ${ }^{3}$ \\ ${ }^{1}$ Graduate School of Bogor Agricultural University, Study Program of Biotechnology, Bogor, Indonesia \\ ${ }^{2}$ Bogor Agricultural University, Department of Biology, Faculty of Mathematics and Natural Sciences, Bogor, Indonesia \\ ${ }^{3}$ Bogor Agricultural University, Department of Animal Nutrition Feed Technology, Faculty of Animal Science, Bogor, Indonesia
}

\begin{abstract}
This experiment aimed to screen some cellulose- and lignin-degrading fungal species for improving nutritive quality of ruminant feed. Fungal species used were Ganoderma lucidum, Pleurotus ostreatus, Phanerochaete chrysosporium, and Trametes visicolor. These fungal species were grown on Potato Dextrose Broth (PDB) medium that added with $0.5 \mathrm{~g}$ substrate, i.e. either rice straw, rice bran or carboxymethyl cellulose for 12 days at room temperature. Harvesting was performed in order to separate fungal mycelium and supernatant that contained crude cellulase enzyme. Among the fungi observed, Ganoderma lucidum had the highest cellulase activity, i.e. $4.02 \mathrm{U} / \mathrm{mg}$. Cellulase activities of Pleurotus ostreatus, Phanerochaete chrysosporium, and Trametes visicolor were 1.53, 1.08, and 0.13 U/mg, respectively. Ganoderma lucidum was further investigated for its ligninolytic enzyme activity, i.e. laccase and manganese peroxidase. It was observed that the fungi had laccase and manganese peroxidase activities of 368.95 and $33.89 \mathrm{U} / \mathrm{mL}$, respectively. Crude enzymes of Ganoderma lucidum that contain cellulase, laccase and manganese peroxidase were further used to increase nutritive quality of rice straw and subjected to in vitro incubation with rumen fluid of cattle.
\end{abstract}

\section{Introduction}

Forage feed is the main source of food ingredients from ruminant livestock to serve as a basic necessity in optimizing productivity. The availability of forage is increasingly limited due to grazing or grass planting being used for industrial and housing-puroses [1]. The alternative to fulfill the needs of livestock feed is by utilizing agricultural and plantation wastes, especially rice straw waste, which is available in abundance during peasant harvest season. The problem is that the utilization is still lacking due to the farmers' limited knowledge, and thus nutrient of rice straw is very low and high in lignin, cellulose, hemicellulose and silica [2]. The constituent component is difficult to degrade by ruminants with digestibility reaching only about $30 \%$ in the rumen [3].

Several ways can be done to help the process of lignocellulose degradation in rice straw namely physical, chemical, and biological. The most appropriate and safe method is by biological means by utilizing white-rot fungi capable of producing lignocellulosic enzymes (Lip, $\mathrm{MnP}$ and Lacc) [4]. However, some industries in Indonesia still use enzyme products from abroad that are very expensive. Several researchers have conducted studies using white-rot fungi from basidomicota class to degrade lignocellulose in rice straw research but this was not comprehensively researched [5]. For that, Indonesia which is known as mega-biodiversity, it is necessary to do research to find microbes such as white-rot fungi that degrades cellulose and lignin on rice straw. Therefore, this study aims to screening white-rot fungi of celluloseand lignin-degrading fungi for improving nutritive quality of ruminant feed on agricultural substrate.

\section{Materials and Methods}

\subsection{Cultivation of white-rot fungi}

White-rot fungi used are Phanerocaeta crysosporium, Pleurotus ostreatus, Trametes versicolor, and Ganoderma lucidum from INACC - microorganism culture collection LIPI - Indonesia. Each fungi were taken using loop and then grown on petri dish media for rejuvenation (from stock culture). The culture was incubated at $28^{\circ} \mathrm{C}$ for 7 days.

\subsection{Production of enzyme extracts}

The medium for enzyme production contained $50 \mathrm{ml}$ Potato Dextrose Broth (PDB) added with 0.5 grams of substrate straw, bran, or carboxymethylcellulose (CMC). The medium is sterilized at $121^{\circ} \mathrm{C}, 2 \mathrm{~atm}$ for $15-30$ minutes, then inoculated with fungus $\left(1 \times 1 \mathrm{~cm}^{2}\right)$ and incubated for 12 days on a reciprocal shaker machine at $120 \mathrm{rpm}$ at room temperature $\left( \pm 27^{\circ} \mathrm{C}\right)$. After 12 days the

\footnotetext{
* Corresponding author: muhamadfauzi426@gmail.com
} 
inoculum was harvested and separated between substrate and supernatant by using Whatman no.1 filter paper and centrifuged at $5000 \mathrm{rpm}$. The supernatant consist of crude enzyme which used for the determination of cellulase and lignocellullase activity.

\subsection{Cellulase activity test}

The enzyme activity was tested by using Miller method [6]. A total of $1 \mathrm{~mL}$ substrate (CMC, straw, bran, and without substrate only PDB medium) was dissolved in $0.05 \mathrm{M}$ phosphate buffer $\mathrm{pH} 7$, added with $1 \mathrm{~mL}$ of crude enzyme and then homogenized with vortex. The solution was incubated for 30 minutes at $37^{\circ} \mathrm{C}$. For the isolate grown in the available PDB, the substrate used to react the enzyme is CMC. The solution that had been added with the dinitrosalisilic acid (DNS) was boiled at $100^{\circ} \mathrm{C}$ for 15 minutes to stop the reaction. The cold solution measured the absorbance at a wavelength of 540 nm. Glucose is used as product standard with concentration of $0.1-0.6 \mathrm{mg} / \mathrm{ml}$. The measurements of protein concentation was performed using Bradford method [7]. Bovine serum albumin (BSA) is used as protein standard in the range $0.1-0.6 \mathrm{mg}$ protein $/ \mathrm{mL}$.

\subsection{Determination of quantitative ligninolitic activities}

Measurements of Lignin Peroxidase (LiP) production were carried out in accordance with the methods of [8]. A number of enzyme supernatants (depending on the type of carbon source of the enzyme origin) are added to the tartrate buffer solution ( $\mathrm{pH} 2.5)$, so the amount of the mixture reached $3 \mathrm{ml}$. This mixture was then added to 1 $\mathrm{ml}$ of $2 \mathrm{mM}$ veratril alcohol, and $1 \mathrm{ml}$ of $\mathrm{H}_{2} \mathrm{O} 20.4 \mathrm{mM}$. The mixture was further homogenized and incubated for 15 minutes at room temperature. The amount of veratraldehid formed is read at a wavelength of $310 \mathrm{~nm}$. Meanwhile for the control, the mixture was immediately boiled at $60^{\circ} \mathrm{C}$ for 5 minutes. The enzyme activity was expressed in equivalent units of 1 unit of enzyme produced per minute from the treatment of $1 \mathrm{ml}$ of the enzyme which was reacted under the condition, while the specific activity is expressed in enzyme activity per mg of protein.

Measurements of Manganese Peroxide (MnP) were performed in accordance with the method [9]. $1750 \mu \mathrm{L}$ buffer malonate $50 \mathrm{mM} \mathrm{pH} 4.5$ was added into quvet then mixed with $125 \mu \mathrm{L}$ 2,6-DMP $20 \mathrm{mM}, 125$ $\mu \mathrm{LMnSO} 420 \mathrm{mM}$, and $300 \mu \mathrm{L} \mathrm{H} 2 \mathrm{O} 22 \mathrm{mM}$. Then shaken and measured absorbance $470 \mathrm{~nm}$. The absorbance reading was performed for 1 minute interval of 20 seconds. The enzyme activity is the amount of enzyme needed to oxidize $1 \mathrm{nmol} 2,6$-DMP er minute units. Manganese peroxidase activity was calculated using the same formula as the 3.5.3 ', 5'-tetrametoxy4,4'-diphenocquinone lacase activity $=49600 \mathrm{M}-1 \mathrm{~cm}-1$.

Measurement of laccase enzymes used the method [10], plated $750 \mu \mathrm{L}$ acetate buffer $0.1 \mathrm{M} \mathrm{pH} 5.3$ and transferred into quvet and added $100 \mu \mathrm{L}$ syringaldazine $0.5 \mathrm{mM}$, then added $900 \mu \mathrm{L}$ of enzyme extract. After that in shake and measured using a $525 \mathrm{~nm}$ spectrophotometer. The absorbance readings are performed at intervals of 1 minute 2 second intervals. Enzyme activity is defined as the amount of enzyme needed to oxidize $1 \mathrm{nmol}$ syrinagaldazine per minute unit.

\section{(At-A0)xVtot(mL)x10}

Enzymes Activites =

$$
\text { Emaks x d x V enzyme (mL) x t }
$$

$$
\begin{array}{ll}
\text { At } & =\text { absorbance at minute to- } \mathrm{t} \\
\text { A0 } & =\text { absorbance at minute to- } 0 \text { (value-0 } \\
& \text { (autozero measurements) }
\end{array}
$$

\section{Results and Discussion}

Ganoderma lucidum is an isolate that has the highest cellulase activity on medium (PDB + bran) is $4.02 \mathrm{U} / \mathrm{mg}$. Other fungi have Pleurotus ostreatus activity $1.53 \mathrm{U} / \mathrm{mg}$ (PDB+CMC), Phanerochaete chrysosporium $1.08 \mathrm{U} / \mathrm{mg}$ (PDB+Bran), Trametes versicolor $0.13 \quad \mathrm{U} / \mathrm{mg}$ (PDB+Bran), (Table 1).

Table 1. The average value of specific activity of white -rot fungi isolates on different substrates.

\begin{tabular}{|c|c|c|c|c|}
\hline \multirow{2}{*}{ Fungi Isolates } & \multicolumn{4}{|c|}{ Different types of substrate } \\
\cline { 2 - 5 } & $\begin{array}{c}\text { PDB }+ \\
\text { Straw } \\
(\mathrm{U} / \mathrm{mg})\end{array}$ & $\begin{array}{c}\text { PDB }+ \\
\text { Bran } \\
(\mathrm{U} / \mathrm{mg})\end{array}$ & $\begin{array}{c}\text { PDB }+ \\
\mathrm{CMC} \\
(\mathrm{U} / \mathrm{mg})\end{array}$ & $\begin{array}{c}\text { PDB } \\
(\mathrm{U} / \mathrm{mg})\end{array}$ \\
\hline $\begin{array}{c}\text { Trametes } \\
\text { versicolor }\end{array}$ & 0 & 0.13 & 0 & 0 \\
\hline $\begin{array}{c}\text { Pleurotus } \\
\text { ostreatus }\end{array}$ & 0 & 0.08 & 1.53 & 0 \\
\hline $\begin{array}{c}\text { Ganoderma } \\
\text { lucidum }\end{array}$ & 0 & 4.02 & 0 & 0 \\
\hline $\begin{array}{c}\text { Phanerochaete } \\
\text { chrysosporium }\end{array}$ & 0 & 1.08 & 0 & 0 \\
\hline
\end{tabular}

The results of the cellulase activity test showed that Ganoderma lucidum isolate had the highest activity of $4.02 \mathrm{U} / \mathrm{mg}$ compared with the other isolates. Plauretus ostreatus had a second highest activity of $1.53 \mathrm{U} / \mathrm{mg}$, Phanerochaete chrysosporium $1.08 \mathrm{U} / \mathrm{mg}$ and Trametes versicolor $0.13 \mathrm{U} / \mathrm{mg}$ (Table 1). This is because isolate Ganoderma lucidum is capable of producing more cellulase enzyme compared to the other white-rot fungi isolates. Ganoderma lucidum utilizes PDB+Bran media as a source of energy (the source of carbon and nitrogen) to maximize biomass production and the release of cellulase enzymes as to break cellulose bonds. The resulting extracellular enzymes are lignin peroxidase (Lip), manganese peroxidase (MnP), and laccase (Lac) [11]. Known as lignin modifying enzymes (LMEs). The extracellular enzyme works to break the polysacarida 
bonds of lignin, cellulose and hemicellulose into simple monosaccharides absorb able for the hypha of the fungus to serve as a source of nutrients to sustain life during nutrient scarcity. This is supported by [12]. Stating that the bran has high enough nutrients for the growth of fungi including is protein, carbohydrate, fat, source of vitamins B1, B2, B3, biotin, pantothenic acid and iron, suitable for medium fermentation in the production of acid proteases and mold cellulase [13]. Plauretus ostreatus isolates had a higher activity than Phanerochaete chrysosporium, and Tramites versicolor had the lowest possible activity.

The four isolates of white-rot fungi from the basidomicota groups had the ability to degrade lignocelluloses, but there were many factors that affected the extracellular enzyme ( $\mathrm{LiP}, \mathrm{MnP}$ and Laccase). This can possibly be due to temperature, incubation time at the time of growth of fungus in liquid medium, compromising the enzyme production. The enzymatic activity can be affected by the temperature, $\mathrm{pH}$, and substrate. Each isolate has different characters in terms of the potency of removing extracellular enzyme; fast in LiP, slower in MnP and not all in Lacc. This can be seen from the value of cellulase activity based on Table 1 whose value is quite varied. To determine the ability of Trametes visicolor isolate, Pleurotus ostreatus, Phanerochaete chrysosporium, good optimization during the growth process of isolate can be performed in liquid medium and at the time of enzymatic reaction. The important thing to note is optimization of the time of incubation, temperature, and substrate. Then need to do the optimization of temperature, $\mathrm{pH}$, and buffer, so that the enzyme reaction produced perfect.

Table 2. Protein content of white-rot fungi isolates on different substrates.

\begin{tabular}{|l|l|l|l|l|}
\hline \multirow{2}{*}{ Fungi Isolates } & \multicolumn{4}{|c|}{ Different types of substrate } \\
\cline { 2 - 5 } & $\begin{array}{l}\text { PDB+ } \\
\text { Straw } \\
(\mathrm{mg} / \\
\mathrm{ml})\end{array}$ & $\begin{array}{l}\text { PDB+ } \\
\text { Bran } \\
(\mathrm{mg} / \\
\mathrm{ml})\end{array}$ & $\begin{array}{l}\text { PDB+ } \\
\mathrm{CMC} \\
(\mathrm{mg} / \\
\mathrm{ml})\end{array}$ & $\begin{array}{l}\text { PDB+ } \\
(\mathrm{mg} / \\
\mathrm{ml})\end{array}$ \\
\hline $\begin{array}{l}\text { Trametes } \\
\text { versicolor }\end{array}$ & 0.50 & 0.64 & 0.66 & 0.75 \\
\hline $\begin{array}{l}\text { Pleurotus } \\
\text { ostreatus }\end{array}$ & 0.50 & 0.60 & 0.60 & 0.50 \\
\hline $\begin{array}{l}\text { Ganoderma } \\
\text { lucidum }\end{array}$ & 0.58 & 0.73 & 0.94 & 0.66 \\
\hline $\begin{array}{l}\text { Phanerochaete } \\
\text { chrysosporium }\end{array}$ & 0.72 & 0.77 & 0.52 & 0.58 \\
\hline
\end{tabular}

Table 3. Lignolytic enzyme test of Ganoderma lucidum of various substrate types.

\begin{tabular}{|l|l|l|l|l|}
\hline Enzim & $\begin{array}{l}\text { PDB+ } \\
\text { Straw } \\
(\mathrm{U} / \mathrm{mL})\end{array}$ & $\begin{array}{l}\text { PDB+ } \\
\text { Bran } \\
(\mathrm{U} / \mathrm{mL})\end{array}$ & $\begin{array}{l}\text { PDB+ } \\
\text { CMC } \\
(\mathrm{U} / \mathrm{mL})\end{array}$ & $\begin{array}{l}\text { PDB } \\
(\mathrm{U} / \mathrm{mL})\end{array}$ \\
\hline Laccase & 368.95 & 0 & 0 & 0 \\
\hline $\begin{array}{l}\text { Mangan } \\
\begin{array}{l}\text { Piroksidase } \\
(\mathrm{MnP})\end{array}\end{array}$ & 33.89 & 1.27 & 1.50 & 0.12 \\
\hline
\end{tabular}

A cellulase activation screening test was performed first to determine which fungi isolate had the highest cellulase activity and continued lignolytic enzyme test. Based on the specific activity test of Ganoderma lucidum fungi in Table 1. the highest cellulase activity was $4.02 \mathrm{U} / \mathrm{mg}$. Then lignolitic activity test that measures the activity of $\mathrm{MnP}$ and laccase on various substrates. Based on the results of the test in Table 3., the highest lignolytic activity occured in the straw substrate i.e. enzyme activity laccase was $368.95 \mathrm{U} / \mathrm{mL}$ and $\mathrm{MnP}$ $33.89 \mathrm{U} / \mathrm{mL}$. This was because the lignin content in straw was higher than in other substrates such as bran, and CMC. Ganoderma lucidum effectively broke the polysacharide bonds to be the simplest monomer seen from the laccase and $\mathrm{MnP}$ resulting the highest lignolytic activity compared to the other isolates (Table 3 ). Straw substrate was rich in carbon source because it is composed of lignin, cellulose and hemicellulose, which can be utilized when the main source of nutrition such as PDB is up. The binding of lignin, cellulose and hemicellulose is broken and converted into a simple monomer called glucose. Based on the lignocellulosic test, Ganoderma Lucidum isolate was capable of producing lignocellulosic enzymes namely $\mathrm{MnP}$ and laccase. This is supported by [14-17] who said that white-rot fungis have $\mathrm{LiP}, \mathrm{MnP}$ and laccase enzymes that are used to break the polysacharide bonds in rice straw. This is distinguished from other substrates when Ganoderma lucidum grown on bran substrate, and CMC lower lignolytic activities. This is probably because Ganoderma lucidum does not need to remove more abundant extract enzymes because the structure of bran and CMC is amorphous and bran, especially contains a high amount of nutrients rich in absorbed vitamins that only form mushroom biomass and do not excrete extracellular enzymes.

\section{Conclusion}

From the four white-rot fungi isolates used to test the lignocellulose degradation potential of rice straw as livestock feed, only Ganoderma lucidum isolate has the highest cellulase activity which can potentially be used as feed additive of ruminants feed after testing lignolytic activity for isolate Ganoderma lucidum on various substrates. Ganoderm lucidum has the highest lignolytic activity occuring in isolates grown in straw. So that isolate of Ganoderma lucidum is potential to be used as a producer of crude enzyme extract which in turn can be used as feed additive for pre-tretmen of straw to increase quality of rice straw. This is expected to help farmers in utilizing agricultural wastes, especially rice straw as a substitute animal feed during the dry season.

\section{References}

1. A Mulyani, M Sarwani, I Las, F Agus, D Kuncoro, Sahidin M. Bogor (ID): Balai Besar Litbang Sumberdaya Lahan Pertanian. (2013)

2. M Lamid, C Siti, TPN Ni Nyoman, Kusmartono. J Protein. 14 : 122-128 (2006) 
3. JA Syamsu. (http://jasmal.blogspot. com/kajianpenggunaan-starter-mikroba-dalam.html) (2007)

4. DS Arora, M. Gill PK Chander. World J. Microbiol. Biotechnol. 21 : 1021-1028. (2005)

5. MAM. Rodrigues, P. Pinto, RMF. Bezerra, AA. Dias, CVM. Guedes, MG. Cardoso, JW Conec, LMM. Ferreira, CA. J. Sequeira Colaco. Animal Feed Science and Technology. 141: 326-338. (2007)

6. GL. Miller. J Anal Chem. 31:426-428. (1959)

7. MM. Bradford, Anaytical Biochemistry. 72 : 248254. (1976)

8. AM. Bonenn, LH. Anton, AB. Orth, Appied and Environmental Microbiology. 60 : 960-965. (1983)

9. H. Wariishi, K. Valli, MH. Gold. J Biol Chem. 267(33):23688-23695. (1992)

10. A. Leonowicz, K. Grzywnowicz. Enzyme Microb Technol. 3:55-58. (1981)

11. RL. Howard, E. Abotsi, EL Jansen van Rensburg, S. Howard. Afr J of Biotechnol 2:602-619. (2003)

12. L. Ikasari, \& D.A. Mitchell. World J.Microbiol. Biotechnol., 19, 171-175. (1994).

13. Y. Sudaryati, \& D. D. Sastraatmadja. J. Mikrobial. Indonesia, 2(2), 30-32. (1993).

14. DS. Arora, M. Chander, PK. Gill. International Biodeterioration and Biodegradation. 50 : 115-120. (2002).

15. C.K, Novotny, P. Svobodova, T. Erbanova, A. Cajthaml, E. Kasinath, Lang and V. Sasek. Soil Biol. Biochem. 36:1545-1551. (2004)

16. DS. Arora, M.Gill PK. Chander. World J. Microbiol. Biotechnol. 21 : 1021-1028. (2005)

17. BE. Lechner, VL. Papinutti, Process Biochemistry. 41: 594-598. (2006) 